\title{
Lagerstroemia L. from the middle Miocene Siwalik deposits, northern India: Implication for Cenozoic range shifts of the genus and the family Lythraceae
}

\author{
Gaurav Srivastava $^{1, *}$, Rajan Gaur $^{2}$ and R C Mehrotra ${ }^{1}$ \\ ${ }^{1}$ Birbal Sahni Institute of Palaeobotany, 53 University Road, Lucknow 226 007, India. \\ ${ }^{2}$ Department of Anthropology, Panjab University, Chandigarh 160 014, India. \\ ${ }^{*}$ Corresponding author. e-mail: gaurav_jan10@yahoo.co.in
}

Fossil leaves of Lagerstroemia (Lythraceae) are described from the Siwalik deposits (middle Miocene) of Kathgodam, Uttarakhand, India. The fossil records of the Lythraceae indicate its worldwide distribution in the Cenozoic. The family had its widest distribution during the Miocene but became less widespread during the Pliocene, followed by range expansion during the Quaternary. The present leaf fossil, along with the previous fossil records of Lagerstroemia, indicates that the genus followed the same pattern of expansion and retraction as the entire family Lythraceae suggesting that both the genus and the family adapted in similar ways. The fossil plant assemblage from the Lower Siwalik deposits indicates warm and humid climate with plenty of rainfall in the region during the depositional period.

\section{Introduction}

The family Lythraceae consists of $\sim 31$ genera and 600 species distributed mainly in tropical and subtropical areas of the Old World (18 genera) and New World (13 genera) (figure 1), and includes four small, previously independent families, i.e., Duabangaceae, Punicaceae, Sonneratiaceae, and Trapaceae (Graham et al. 2005). The Lythraceae has been placed in the order Myrtales with closely allied family Onagraceae based on the morphological, anatomical, embryological, and molecular studies (Dahlgren and Thorne 1984; Johnson and Briggs 1984; Conti et al. 1997; Sytsma et al. 2004). On the basis of molecular data it was suggested that the Lythraceae diverged from the Onagraceae at $93 \mathrm{Ma}$, i.e., in the early Late Cretaceous (Sytsma et al. 2004); however, the oldest fossil records of the family (pollen grains) are from the early Campanian (81-82 Ma) of Wyoming, USA (Grimsson et al. 2011).
Lagerstroemia (crape myrtle) is a genus of $\sim 53-$ 56 species of deciduous and evergreen trees and shrubs native to the Indian subcontinent, southeast Asia, northern Australia, and parts of Oceania (figure 1) (Mabberley 1997; Graham 2013). The genus mainly grows in lowland swamps and montane and secondary forests (Graham 2013). Lagerstroemia, along with other taxa such as Sonneratia L.f., Duabanga Buch.-Ham. and Trapa L. form a subclade of one of the two major clades of the family Lythraceae (Graham et al. 2005; Morris 2007). The genus is economically very important as it is used as timber, fuel, and fodder and is also used in making drugs for diabetes (Judy et al. 2003).

In the present communication a new fossil leaf of Lagerstroemia is described from the Siwalik sediments of northern India (figure 2). The evolutionary history, expansion, and phytogeography of the genus and its family in the geological context are also discussed.

Keywords. Miocene; northern India; palaeoclimate; phytogeography; Siwalik. 


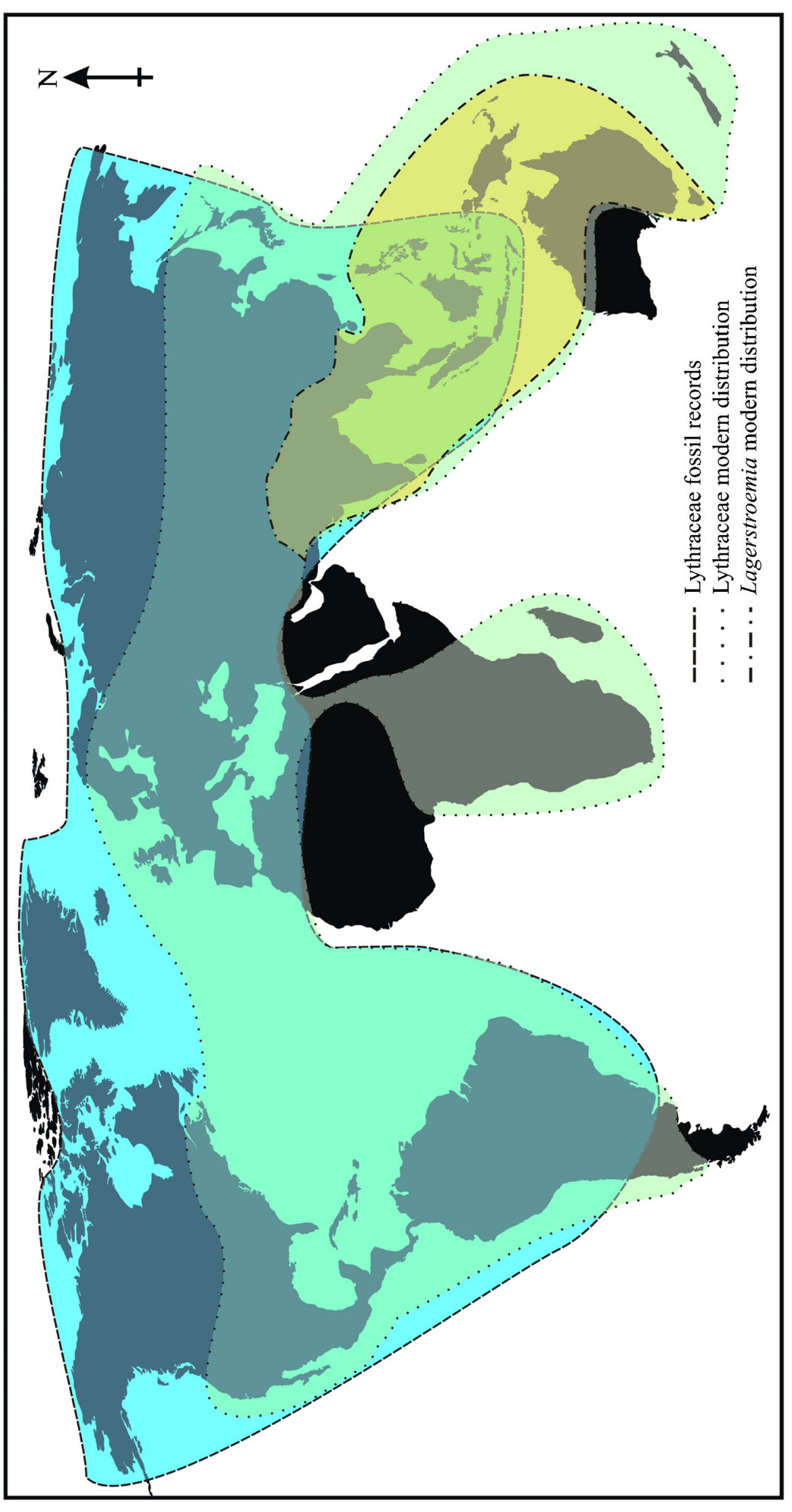

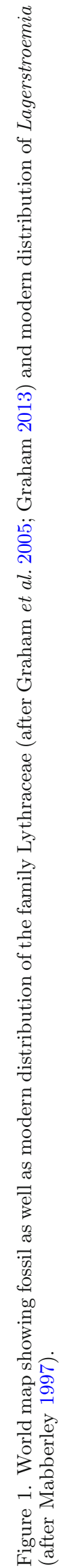




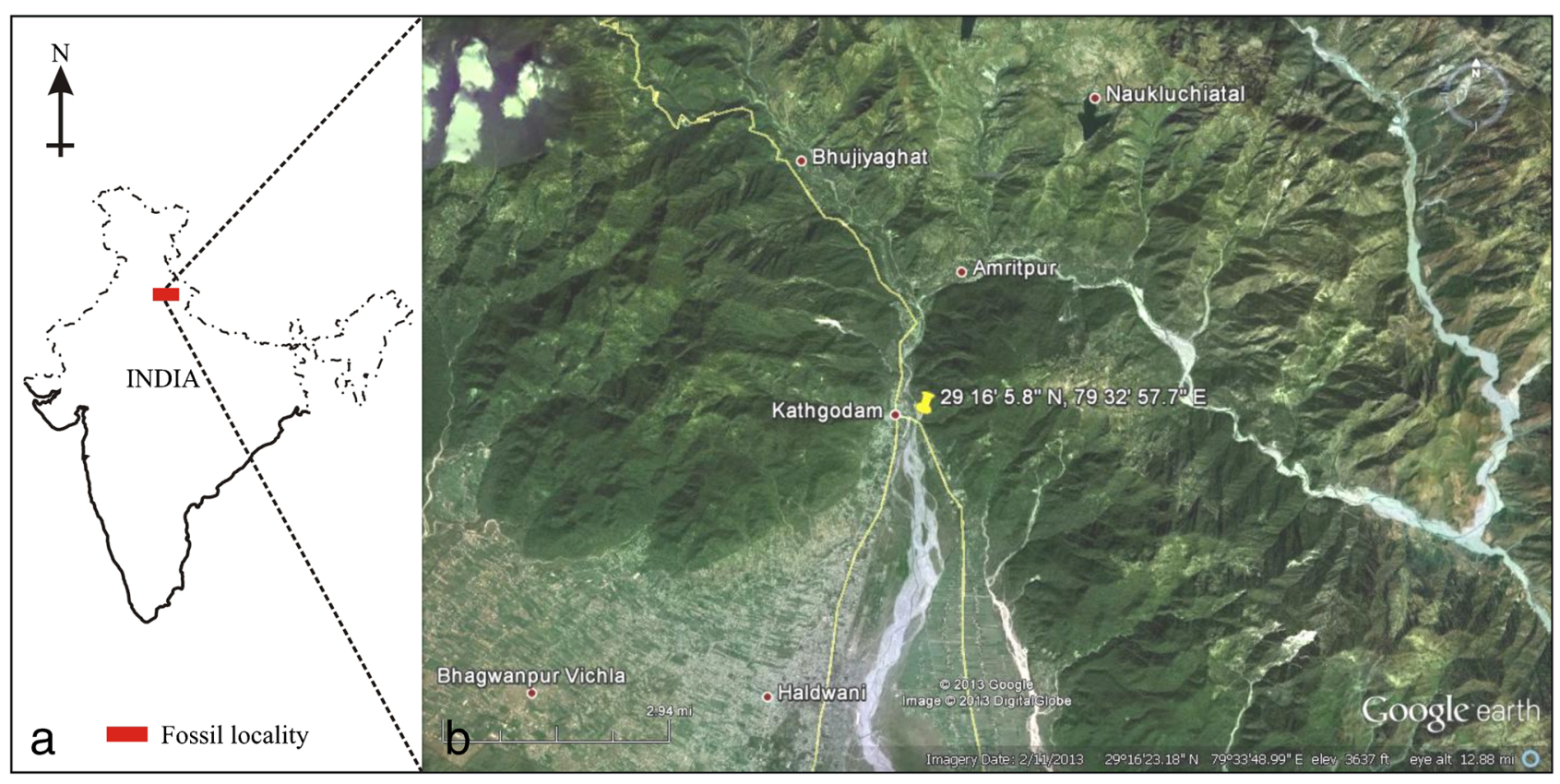

Figure 2. (a) Map of India showing the fossil locality (red solid rectangle). (b) High resolution map showing the fossil locality (marked with yellow spot).

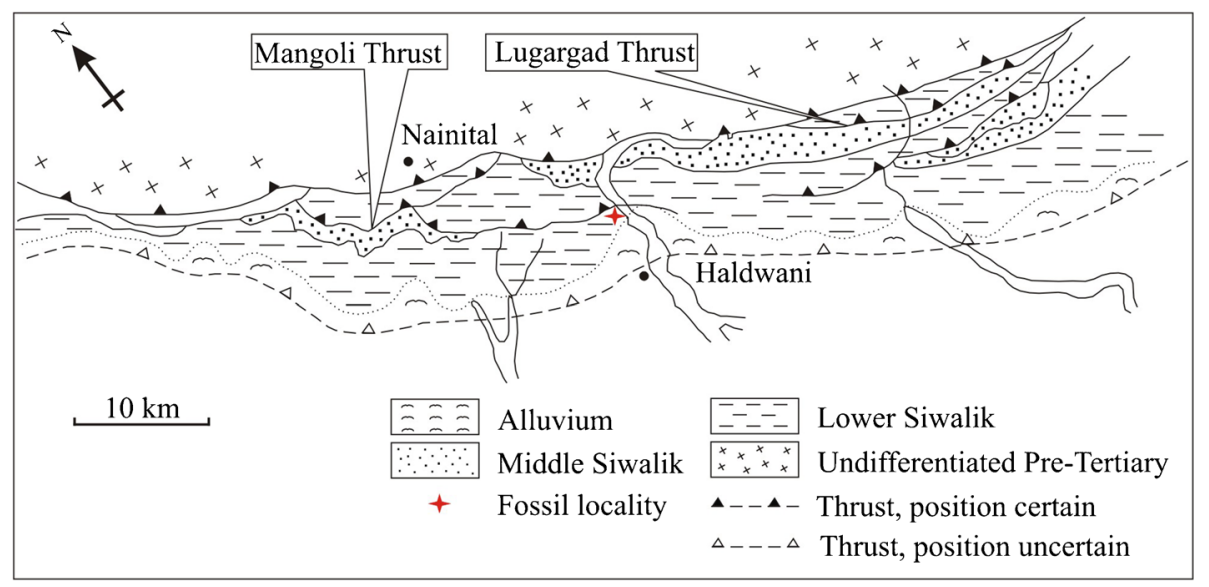

Figure 3. Geological map of the fossil locality (Ranga Rao et al. 1979).

\section{Materials and methods}

For better understanding of the floristics and palaeoclimate of Kathgodam Siwalik, an excursion was undertaken by one of us (RG), who collected a few fossil leaves from the yellowish grey mudstone exposed along the Gola River near Kathgodam, Nainital District of Uttarakhand (figure 2). The geology of the area has been given by Middlemiss (1890), Heim and Gansser (1939), Tiwari and Mehdi (1964), Fuchs and Sinha (1974) and Ranga Rao et al. (1979). According to them, the Siwaliks are exposed in this area all along the main boundary thrust in the southwest and are overridden by the Krol Group rocks (Fuchs and Sinha 1974). The Siwalik beds in the aforesaid area are found running in a northeast direction (figure 3). The area is characterized by the middle Miocene Lower Siwalik deposits (Ranga Rao et al. 1979). These deposits are made up of alternating layers of medium-grained sandstones and mudstones and an age between 10.8 and $18.3 \mathrm{Ma}$ was assigned to them on the basis of palaeomagnetic investigations in the Pakistan Siwalik (Gaur 1987). According to Tandon (1976), the Lower Siwalik of Kumaon Himalaya probably indicates a fluviatile and deltaic environment.

After cleaning the surface of the leaves, the fossils were photographed under low angled sunlight using a 10 megapixel digital camera (Canon SX 110). The terminology used in describing the fossil leaf is based on Hickey (1973), Dilcher (1974) and 
Ellis et al. (2009). The leaf fossils were identified at the Central National Herbarium (CNH), Howrah, the Forest Research Institute (FRI), Dehradun, and the Birbal Sahni Institute of Palaeobotany, Lucknow after comparing them with herbarium material of the extant plants. The fossil specimens are deposited in the museum of the Birbal Sahni Institute of Palaeobotany, Lucknow. The accepted fossil records of Lythraceae and Lagerstroemia as provided by Graham (2013) are discussed in view of the new fossil.

\section{Systematic description}

Family: Lythraceae J. St.-Hil.

Genus: Lagerstroemia L.

Species: Lagerstroemia himalayaensis, Srivastava, Gaur et Mehrotra, sp. nov. (figure 4A, B, $\mathrm{D}, \mathrm{E})$

Holotype: Specimen no. BSIP 40116.

Paratype: Specimen no. BSIP 40117.

Horizon: Lower Siwalik.

Locality: Gola River near Kathgodam, Nainital District of Uttarakhand.

Age: Middle Miocene.

Material: Two well preserved specimens.

Etymology: After the Himalaya.

Description: Leaf simple, symmetrical, mesophyll, elliptic to narrow elliptic; preserved lamina length and width $6.1 \times 3.1 \mathrm{~cm}$ and $7 \times 3 \mathrm{~cm}$; apex acuminate with round tip; base acute; margin entire, slightly wavy; texture supposedly chartaceous; petiole not preserved; venation pinnate, eucamptodromous to brochidodromous; primary vein stout, almost straight; nine pairs of secondary veins, $0.5-0.9 \mathrm{~cm}$ apart, predominantly alternate, angle of divergence moderate to wide acute $\left(49^{\circ}-\right.$ $69^{\circ}$ ), uniformly curved and running parallel to each other up to the margin, sometimes turning sharply upwards near the margin to form loops with the adjacent secondaries at the upper part of lamina, moderately thick; intersecondary veins present, 1 or 2 in number; tertiary veins percurrent, simple, rarely forked, recurved, oblique in relation to midvein, angle of origin predominantly acute-obtuse $(\mathrm{AO})$; marginal ultimate venation looped.

Affinities: The characteristic features of the fossil leaves, specifically the elliptic to narrow elliptic shape, eucamptodromous to brochidodromous venation, moderate to wide acute angle of divergence of secondary veins, percurrent and recurved oblique tertiary veins suggest their close affinity with Lagerstroemia of the family Lythraceae. A large number of taxa of many tropical and subtropical families like Anacardiaceae, Annonaceae,
Combretaceae, Euphorbiaceae, Moraceae, Myrtaceae, Polygalaceae, Phyllanthaceae, Rutaceae, Sapindaceae, Sapotaceae, and Simaroubaceae were studied and compared with the present fossil. Anacardium occidentale, Parishia maingayi, and Taxicodandron acuminatum of the Anacardiaceae, Alphonsea lutea, Oxymitra fornicata of the Annonaceae, Combretum decandrum, Illigera khasiana, Terminalia chebula of the Combretaceae, Hancea penangensis of the Euphorbiaceae, and Artocarpus integrifolia and Ficus pumila of the Moraceae show most resemblance but the presence of character combinations such as an attenuate apex, eucamptodromous venation and reticulate tertiaries differentiates the fossil. Pimenta dioica of the Myrtaceae has obtuse base and brochidodromous venation while in Psidium guineense secondary veins are moderately acute and the venation is eucamptodromous, which distinguishes them from the present fossil.

Various taxa of the Lythraceae such as Ammannia baccifera L., Lagerstroemia spp, Lawsonia alba Lamk., Lythrum salicaria L., Punica granatum L., Rotala indica and Woodfordia fruiticosa (L.) Kurz have been compared with the present fossil. In Ammannia baccifera, Lythrum salicaria, and Woodfordia fruiticosa, the venation is brochidodromous. In Lawsonia alba and Rotala indica, the leaves are smaller (nanophyll) in size, while in Punica granatum, the apex is acute and venation is only reticulate. In the present fossil, the apex is acuminate and venation is eucamptodromous to brochidodromous. Among the Lagerstroemia species such as L. calyculata Kurz, L. floribunda Jack, L. hypoleuca Kurz, L. indica Linn., L. minuticarpa Debb. ex Kanjilal, L. parviflora Roxb., L. speciosa (L.) Pers., L. tomentosa Presl, L. turbinata Koehne, L. venusta Wall. ex Clarke, and L. villosa Wall. ex Kurz, it has been inferred that the present fossil is similar to L. parviflora (figure $4 \mathrm{C}, \mathrm{F}$ ) (herbarium sheet nos. $\mathrm{CNH}$ 8629, 10513; FRI:21817 and L. speciosa (herbarium sheet no. FRI 41562). A large number of herbarium sheets of $L$. indica, L. tomentosa and L. villosa were examined. In these species, the apex is attenuate to mucronate and the base is obtuse to round, unlike in our fossil. The presence of simple to forked percurrent and reticulate tertiaries in L. hypoleuca and L. turbinata differentiate them from the present fossil. Leaves of $L$. floribunda are bigger in size $(\sim 16.5 \times 4.8 \mathrm{~cm})$ than our fossil (length and width $6.1 \times 3.1 \mathrm{~cm}$ and $7 \times 3 \mathrm{~cm}$ ), though size is a variable feature. In $L$. minuticarpa, the adjacent secondary veins are not running parallel to each other as in the fossil, while $L$. venusta differs from the fossil in eucamptodromous venation and having attenuate apex. 

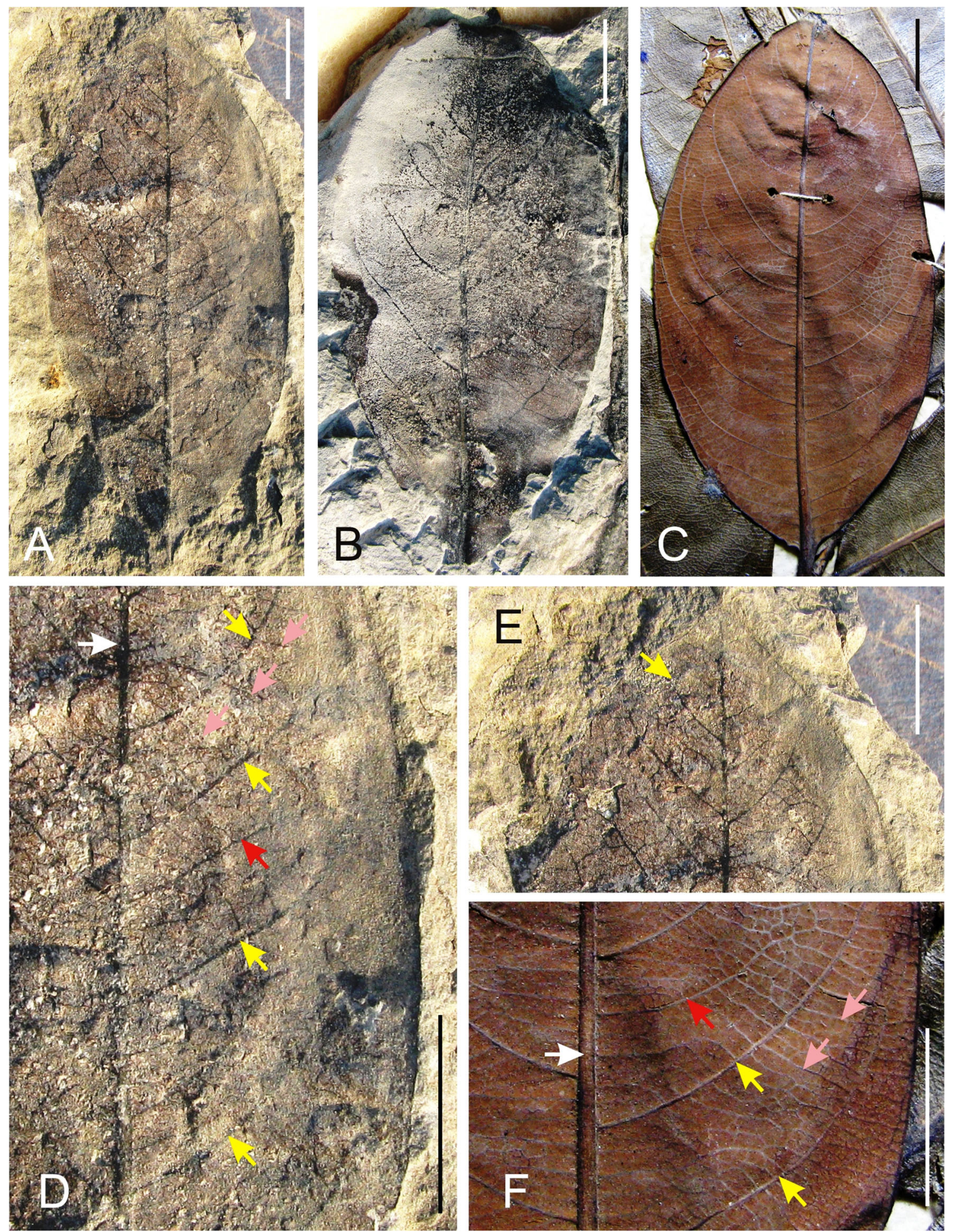

Figure 4. (A) and (B) Fossil leaves of Lagerstroemia himalayaensis sp. nov. (specimen nos. BSIP 40116, 40117) showing shape, size and venation pattern. (C) Modern leaf of L. parviflora showing similar shape, size and venation pattern as in the fossil. (D) Enlarged portion of the fossil leaf showing primary vein (white arrow), secondary veins (yellow arrows), intersecondary vein (red arrow) and percurrent tertiary veins (pink arrows). (E) Enlarged apical portion of the fossil leaf showing brochidodromous venation (yellow arrow). (F) Enlarged portion of L. parviflora showing similar primary vein (white arrow), secondary veins (yellow arrows), intersecondary vein (red arrow) and percurrent tertiary veins (pink arrows) (Bar $=1 \mathrm{~cm}$ unless otherwise mentioned).

As far as the fossil leaf records of Lagerstroemia are concerned, they are known mainly from India and Japan. Lagerstroemia patellii, Lakhanpal and
Guleria (1981) reported from the lower Eocene sediments of Kachchh, differs from the present fossil in having a cuneate base. Two species, namely 
Gaurav Srivastava et al.

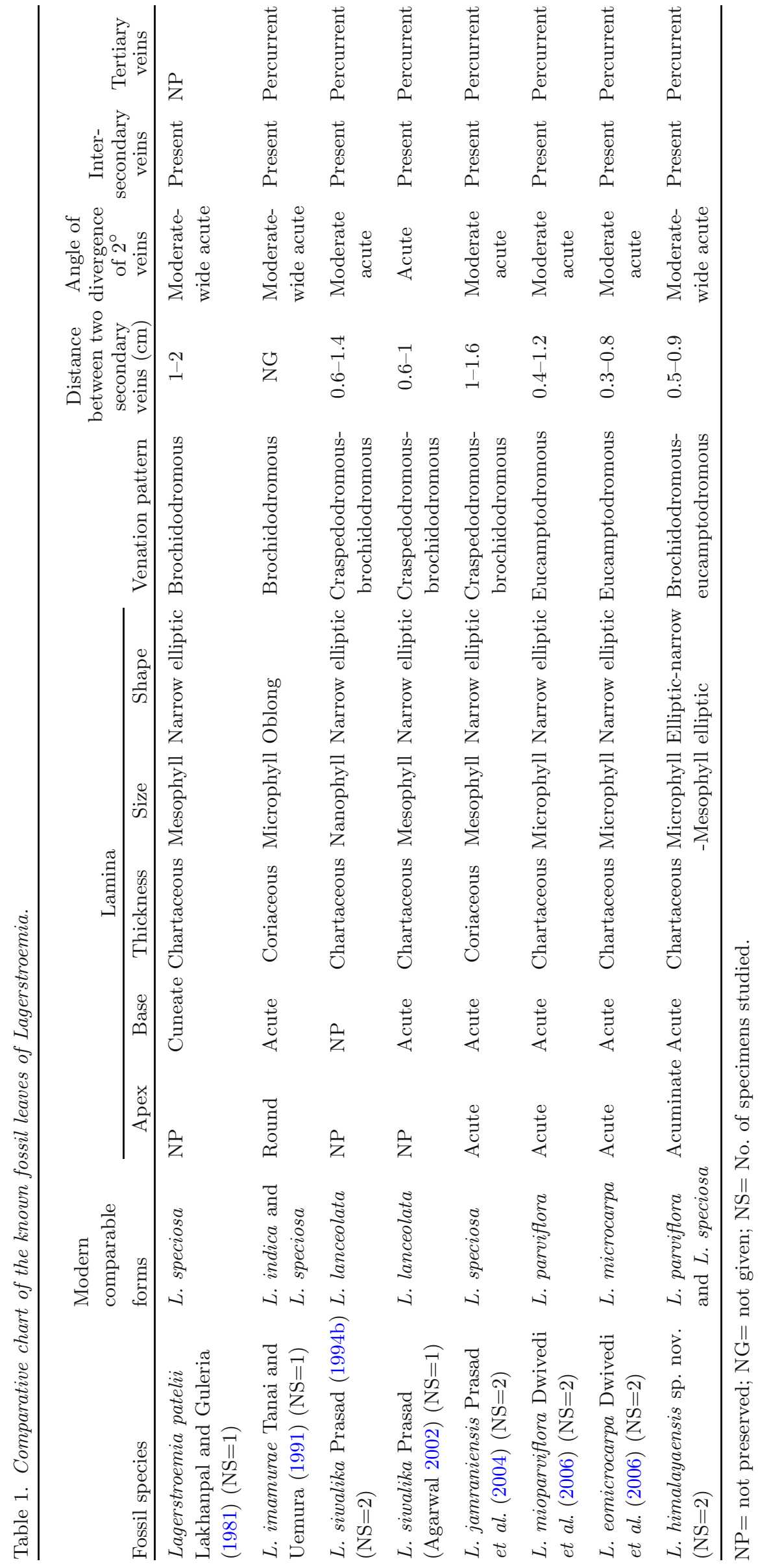


L. siwalika (Prasad 1994b) and L. jamraniensis (Prasad et al. 2004) were reported from the Siwalik sediments of Nepal and northern India. Later, L. siwalika Prasad was again reported from the Miocene sediments of the Neyveli Lignite mine (Agarwal 2002). These fossils have pinnate craspedodromous to brochidodromous venation in contrast to the present fossil, where it is eucamptodromous to brochidodromous. Dwivedi et al. (2006) reported two species, viz., L. mioparviflora and L. eomicrocarpa from the Siwalik of Nepal. Both these fossils have only eucamptodromous venation and the angle of divergence of secondary veins is moderate acute, whereas it is moderate to wide acute in the present fossil. Another fossil L. imamurae Tanai and Uemura (1991) was reported from the Oligocene sediments of Japan, but it is different in being oblong in shape. A comprehensive chart of the character by character comparison of the aforesaid fossils is provided in table 1 . Under these circumstances, the present leaf fossil has been assigned to a new species, Lagerstroemia himalayaensis Srivastava, Gaur et Mehrotra, sp. nov. The modern comparable species, i.e., L. parviflora is distributed on the foothills of the western Himalayas and throughout the Deccan Plateau, while L. speciosa is found from Assam to Malacca abundantly, on the hills of the Deccan Peninsula and in Sri Lanka (Hooker 1879).

\section{Discussion}

\subsection{Origin, diversification, modern distribution, fossil records and range shift of the family Lythraceae}

The modern distribution and fossil records of Lythraceae are very interesting because nowadays the family is restricted only to tropical and subtropical areas, while its fossils have been reported from almost all parts of the globe (figure 1). They have been reported from the Late Cretaceous of USA and Mexico; Deccan Intertrappean beds (late Maastrichtian-Danian) of central India; Paleocene sediments of France and North America; Eocene sediments of North America, Europe, Libya, and south Asia; Oligocene sediments of North America, Europe, Siberia, and Japan; Miocene sediments of North America including Alaska and Canada, Europe, Denmark, south and southeast Asia, Russia, and China; Pliocene sediments of North America including Canada, Europe and China; Quaternary sediments of Panama, Colombia, Brazil, USA, Europe, and south and southeast Asia (Graham 2013). The family expanded after the Eocene, reached its peak during the Miocene (figure 5) and then declined significantly in the Pliocene as the climate deteriorated (Zachos et al. 2001) and now the family is not found in high latitudes such as Alaska, northern Canada, Greenland, and Siberia (figure 1).

Based on the molecular data, Graham et al. (2005) suggested an Old World lauracesian origin of the family but the oldest fossil records (Lythrum and Peplis pollen) from Wyoming, USA indicate that the family was already established by the early Campanian (Late Cretaceous) in the New World Laurasia (Grimsson et al. 2011). The oldest megafossil record is a seed of Decodon described from the late Campanian (Late Cretaceous) of Mexico (Rodríguez-de la Rosa et al. 1998), again suggesting an early diversification of the family in the New World during the Campanian $(\sim 70.6-83.5 \mathrm{Ma})$. Besides the fossil records mentioned above, the next oldest record is from India in the form of a flower (Sahnianthus) and

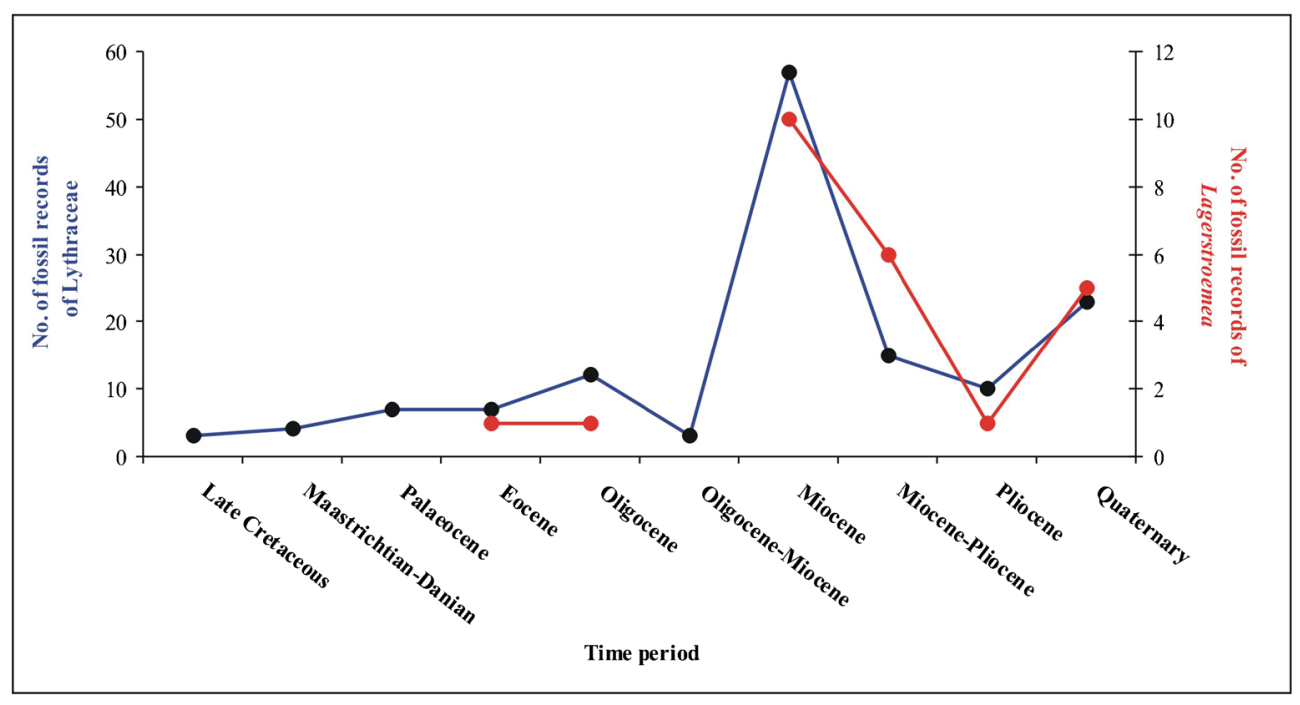

Figure 5. Graph showing number of fossil records of both Lagerstroemia and Lythraceae in the geologic past. 
Table 2. Fossil assemblage of Lower Siwalik (middle Miocene) of Kathgodam.

\begin{tabular}{|c|c|c|c|}
\hline Fossil taxa & Modern comparable species & Forest types & References \\
\hline \multicolumn{4}{|l|}{ Monocotyledons } \\
\hline \multicolumn{4}{|l|}{ Marantaceae } \\
\hline Alpinia siwalica Prasad et al. & A. buteocarpa Poepp. & Evergreen & Prasad et al. (2004) \\
\hline Clinogyne ovatus Awasthi et Prasad & C. grandis Benth. et $\mathrm{Hk}$. & Moist deciduous & Prasad et al. (2004) \\
\hline \multicolumn{4}{|l|}{ Poaceae } \\
\hline Bambusa siwalika Awasthi et Prasad & B. tulda Roxb. & Moist deciduous & Prasad et al. (2004) \\
\hline \multicolumn{4}{|l|}{ Dicotyledons } \\
\hline \multicolumn{4}{|l|}{ Achariaceae } \\
\hline Gynocardia mioodorata Prasad et al. & G. odorata R. Br. & Evergreen & Prasad et al. (2004) \\
\hline Hydnocarpus palaeokurzii Prasad & H. kurzii (King) Wrab & Evergreen & Prasad (1994a) \\
\hline \multicolumn{4}{|l|}{ Anacardiaceae } \\
\hline Holarrhena nainitalensis Prasad et al. & H. antidysentrica Wall. & Mixed deciduous & Prasad et al. (2004) \\
\hline \multicolumn{4}{|l|}{ Annonaceae } \\
\hline Cananga tertiara Prasad et al. & C. odorata Hk. f. et Thoms. & Evergreen & Prasad (1994a) \\
\hline Saccopetalum pretomentosum Prasad et al. & S. tomentosum Hk. f. et Thoms. & Moist deciduous & Prasad et al. (2004) \\
\hline Uvaria siwalika Prasad & U. hamiltonii Hk. f. & $\begin{array}{l}\text { Evergreen to moist } \\
\text { deciduous }\end{array}$ & Prasad (1994a) \\
\hline \multicolumn{4}{|l|}{ Apocynaceae } \\
\hline Wrightia siwalika Prasad & W. tinctoria R. Br. & Moist deciduous & Prasad (1994a) \\
\hline \multicolumn{4}{|l|}{ Bixaceae } \\
\hline Bixa kathgodamensis Prasad et al. & B. orellana L. & Evergreen & Prasad et al. (2004) \\
\hline \multicolumn{4}{|l|}{ Capparidaceae } \\
\hline Capparis palaeomicrantha Prasad et al. & C. micrantha DC. & Evergreen & Prasad et al. (2004) \\
\hline \multicolumn{4}{|l|}{ Calophyllaceae } \\
\hline $\begin{array}{l}\text { Calophyllum suraikholaensis Awasthi et } \\
\text { Prasad }\end{array}$ & C. polyanthum Wall. & Evergreen & Prasad et al. (2004) \\
\hline Mesua tertiara Lakhanpal & M. ferrea L. & Evergreen & Prasad (1994a) \\
\hline \multicolumn{4}{|l|}{ Clusiaceae } \\
\hline Garcinia eocambogia Prasad & G. cambogia Roxb. & Evergreen & Prasad (1994a) \\
\hline \multicolumn{4}{|l|}{ Combretaceae } \\
\hline Terminalia miobelerica Prasad et al. & T. belerica Roxb. & $\begin{array}{l}\text { Evergreen to moist } \\
\text { deciduous }\end{array}$ & Prasad (1994a) \\
\hline \multicolumn{4}{|l|}{ Dipterocarpaceae } \\
\hline $\begin{array}{l}\text { Dipterocarpus siwalicus Lakhanpal et } \\
\text { Guleria }\end{array}$ & D. tuberculatus Roxb. & $\begin{array}{l}\text { Evergreen to moist } \\
\text { deciduous }\end{array}$ & Prasad (1994a) \\
\hline Hopea kathgodamensis Prasad & H. micrantha Hk. f. & Evergreen & Prasad (1994c) \\
\hline Shorea miocenica Antal et Prasad & S. buchananii Fischer & Evergreen & Prasad et al. (2004) \\
\hline \multicolumn{4}{|l|}{ Ebenaceae } \\
\hline Diospyros kathgodamensis Prasad & D. cacharensis Naithani & Evergreen & Prasad (1994a) \\
\hline D. palaeoebenum Prasad & D. ebenum Kurz. & Evergreen & Prasad (1994c) \\
\hline D. nainitalensis Prasad et al. & D. chloroxylon Roxb. & Moist deciduous & Prasad et al. (2004) \\
\hline D. palaeoeriantha Prasad et al. & D. eriantha (Champ.) Benth. & Evergreen to moist & Prasad et al. (2004) \\
\hline Euphorbiaceae & & deciduous & \\
\hline Homonoia mioriparia Antal et Prasad & H. riparia Lour. & Moist deciduous & Prasad et al. (2004) \\
\hline Mallotus venkatachalai Prasad & $\begin{array}{l}\text { M. cochinchinensis Lour. and } \\
\text { M. repandus Muell. }\end{array}$ & $\begin{array}{l}\text { Evergreen to moist } \\
\text { deciduous }\end{array}$ & Prasad (1994c) \\
\hline \multicolumn{4}{|l|}{ Fabaceae } \\
\hline Acacia eosericata Prasad & A. sericata A. Cun ex Benth. & Mixed deciduous & Prasad (1994a) \\
\hline Albizia siwalika Prasad & A. lebbek Benth. & $\begin{array}{l}\text { Evergreen to moist } \\
\text { deciduous }\end{array}$ & Prasad (1994a) \\
\hline Cassia siwalica Prasad & C. tora $\mathrm{L}$. & Mixed deciduous & Prasad (1994a) \\
\hline Cynometra palaeoiripa Prasad et al. & C. iripa Kotel & Moist deciduous & Prasad et al. (2004) \\
\hline Derris prakashii Prasad et al. & D. trifoliata Lour. & Evergreen & Prasad et al. (2004) \\
\hline Dialium palaeoindum Prasad & D. indum L. & Evergreen & Prasad (1994a) \\
\hline
\end{tabular}


Table 2. (Continued.)

\begin{tabular}{|c|c|c|c|}
\hline Fossil taxa & Modern comparable species & Forest types & References \\
\hline Millettia kathgodamensis Prasad et al. & $\begin{array}{l}\text { Callerya atropurpurea (Wall.) } \\
\text { Schot (syn. Millettia } \\
\text { atropurpurea Benth.) }\end{array}$ & Evergreen & Prasad et al. (2004) \\
\hline M. palaeoracemosa Awasthi and Prasad & M. racemosa Benth. & Moist deciduous & Prasad (1994a) \\
\hline M. siwalica Prasad & M. ovalifolia Kurz & Moist deciduous & Prasad (1994c) \\
\hline Ormosia robustoides Prasad & O. robusta Wight. & Evergreen & Prasad et al. (2004) \\
\hline Pongamia kathgodamensis Prasad & P. glabra Vent. & $\begin{array}{l}\text { Evergreen to moist } \\
\text { deciduous }\end{array}$ & Prasad $(1994 c)$ \\
\hline Samanea siwalica Prasad et al. & S. saman Merrill & Evergreen & Prasad (1994a) \\
\hline Lauraceae & & & \\
\hline Michilus miocenica Prasad & M. odoratissima Nees. & $\begin{array}{l}\text { Evergreen to moist } \\
\text { deciduous }\end{array}$ & Prasad (1994c) \\
\hline \multicolumn{4}{|l|}{ Lythraceae } \\
\hline Lagerstroemia jamraniensis Prasad et al. & L. speciosa Pers. & Moist deciduous & Prasad et al. (2004) \\
\hline Lagerstroemia patelii Lakhanpal et Guleria & L. flors-reginae Retz. & $\begin{array}{l}\text { Evergreen to moist } \\
\text { deciduous }\end{array}$ & Prasad (1994a) \\
\hline \multicolumn{4}{|l|}{ Malvaceae } \\
\hline Grewia kathgodamensis Prasad et al. & G. laurifolia Hk. & Evergreen & Prasad et al. (2004) \\
\hline Pachira palaeomalabarica Prasad et al. & P. sessilis Benth. & Evergreen & Prasad et al. (2004) \\
\hline Sterculia kathgodamense Prasad & S. coccinea Jack & Evergreen & Prasad (1994a) \\
\hline \multicolumn{4}{|l|}{ Meliaceae } \\
\hline Chukrasia miocenica Prasad & C. tubularis Adr. Juss. & Moist deciduous & Prasad (1994c) \\
\hline Dysoxylum mioklanderi Prasad & D. kalanderi F. Muell. & Evergreen & Prasad (1994c) \\
\hline Toona siwalica Awasthi et Lakhanpal & T. ciliata Roxb. & $\begin{array}{l}\text { Evergreen to moist } \\
\text { deciduous }\end{array}$ & Prasad (1994a) \\
\hline Trichilia miocenica Prasad & T. glabra Vell. & Moist deciduous & Prasad (1994a) \\
\hline \multicolumn{4}{|l|}{ Moraceae } \\
\hline Ficus oodlabariensis Antal et Awasthi & F. benjamina L. & Evergreen & Prasad et al. (2004) \\
\hline Ficus precunea Lakhanpal & F. cunea Ham. & Mixed deciduous & Prasad et al. (2004) \\
\hline \multicolumn{4}{|l|}{ Myrsinaceae } \\
\hline Ardisia palaeosimplicifolia Prasad & A. simplicifolia Walp. & $\begin{array}{l}\text { Evergreen to moist } \\
\text { deciduous }\end{array}$ & Prasad (1994a) \\
\hline \multicolumn{4}{|l|}{ Phyllanthaceae } \\
\hline Glochidion miocenica Prasad & G. chlorophaes Baill. & Evergreen & Prasad (1994a) \\
\hline Phyllanthus mioreticulatus Prasad et al. & $P$. reticulates Poir. & Evergreen & Prasad et al. (2004) \\
\hline P. siwalica Prasad & P. gracilips Muell. Arg. & Evergreen & Prasad (1994a) \\
\hline \multicolumn{4}{|l|}{ Rhamnaceae } \\
\hline Zizyphus kathgodamensis Prasad & Z. xylopyrus Wild. & Mixed deciduous & Prasad (1994a) \\
\hline Z. miocenicus Prasad et al. & Z. jujuba Lam. & Mixed deciduous & Prasad (1994a) \\
\hline \multicolumn{4}{|l|}{ Rosaceae } \\
\hline Parinari kathgodamensis Prasad & P. excelsa Sabine. & Evergreen & Prasad (1994a) \\
\hline \multicolumn{4}{|l|}{ Rubiaceae } \\
\hline Gardenia nainitalensis Prasad & G. jasminoides Retz. & Evergreen & Prasad (1994a) \\
\hline Morinda palaeotinctoria Prasad & M. tinctoria Roxb. & Evergreen & Prasad (1994a) \\
\hline \multicolumn{4}{|l|}{ Rutaceae } \\
\hline Acronychia siwalica Prasad & A. baueri Schott. & $\begin{array}{l}\text { Evergreen to moist } \\
\text { deciduous }\end{array}$ & Prasad (1994c) \\
\hline Geijera siwalica Prasad & G. laurifolia Hk. & Evergreen & Prasad (1994c) \\
\hline \multicolumn{4}{|l|}{ Sapindaceae } \\
\hline Cupania moicenica Prasad et al. & C. jackiana Heirn. & Evergreen & Prasad et al. (2004) \\
\hline Euphoria siwalica Prasad & E. didyma Blanco. & Evergreen & Prasad (1994a) \\
\hline \multicolumn{4}{|l|}{ Sapotaceae } \\
\hline Sarcosperma mioarboratum Prasad et al. & S. arboretum Benth. & Evergreen & Prasad et al. (2004) \\
\hline Theaceae & & Mixed deciduous & Prasad (1994a) \\
\hline Uncobia palaeospinosa Prasad & Stewartia L. & & \\
\hline
\end{tabular}


its associated fruit (Enigmocarpon) discovered from the Deccan Intertrappean beds of central India (Sahni and Rode 1937; Sahni 1943; Shukla 1944, 1958; Chitaley and Kate 1977) considered as late Maastrichtian-Danian in age ( 61.7-65 Ma). On the basis of these records it can be inferred that the family was widely distributed on both the northern and southern hemispheres by the Late Cretaceous ( 65.6-99.6 Ma) (Venkatesan et al. 1993; Shukla et al. 1997; Salis and Saksena 1998).

\subsection{Fossil records of Lagerstroemia}

The fossil records of Lagerstroemia are represented in the form of wood, leaf, and pollen which are restricted to south and southeast Asia, China, and Japan. In south Asia, the fossils are recorded in the form of leaves and wood from the Eocene, Miocene, and Mio-Pliocene sediments of India and Nepal (Prakash and Tripathi 1970; Awasthi 1981; Lakhanpal and Guleria 1981; Lakhanpal et al. 1981; Srivastava and Bande 1992; Antal and Awasthi 1993; Prasad 1994b; Agarwal 2002; Prasad et al. 2004; Dwivedi et al. 2006). Similarly, the genus was recorded as pollen and wood from the Neogene sediments of southeast Asia (Prakash 1965a, b; Prakash 1972; Kramer 1974; Prakash and Bande 1980; Du 1988; Guleria 1989; Watanasak 1990; Songtham et al. 2005). Fossils of the genus have also been reported from the Oligocene and Neogene sediments of Japan (Tanai and Uemura 1991; Miyoshi et al. 1999; Fujiki et al. 2001; Momohara et al. 2006; Choi et al. 2010). Its pollen and wood are also known from the Miocene and Pliocene of eastern and southwestern China (Cheng et al. 2007; Liu et al. 2008). Among all these fossil records, the oldest is from the Eocene sediments of Gujarat (Lakhanpal and Guleria 1981), India suggesting a probable Gondwanic origin of the genus. The aforesaid fossil records of Lagerstroemia, at least in south and southeast Asia, suggest that the genus might have migrated from India to southeast Asia after the complete suturing of the Indian and Eurasian plates. Like Lagerstroemia, many other taxa such as Mangifera and Semecarpus of the Anacardiaceae (Mehrotra et al. 1998; Srivastava and Mehrotra 2012; Chatterjee et al. 2013), Alphonsea of the Annonaceae (Srivastava and Mehrotra 2013a), Sterculia of the Malvaceae (Srivastava and Mehrotra 2013b) and Dipterocarpaceae (Dutta et al. 2011) might have migrated from India to southeast Asia. Their migration supports the 'Out of India' hypothesis (Bossuyt and Milinkovitch 2001).

\subsection{Expansion and retraction of Lythraceae and Lagerstroemia during the Cenozoic}

A cursory look at the known fossil records of Lythraceae and Lagerstroemia (figure 5) indicates a pattern of expansion and retraction which showed a maximum peak in the Miocene but dropped abruptly in the Pliocene due to the deterioration in the climatic conditions (Zachos et al. 2001). Both the family and the genus show the same pattern of expansion and retraction suggesting that they had a similar behaviour for adaptation during the Cenozoic. The similar behaviour pattern in adaptation might be because of the ecological niche conservatism (ENC). The ENC, therefore, is defined as the tendency of a species (or clades) to hold their ecological traits over a period of time (Peterson et al. 1999) and this phenomenon is observed not only at regional level but on a global scale as well (Crisp et al. 2009).

\subsection{Palaeoclimate analysis of the fossil locality}

A large number of fossil taxa have been reported from the Siwalik (middle Miocene) of Kathgodam (table 2). The presence of typical megathermal pantropical families like Annonaceae, Bombacaceae, Combretaceae, and Clusiaceae indicates a warm condition with plenty of rainfall. The dominance of evergreen and moist deciduous taxa, along with the mixed deciduous taxa (figure 6) indicates seasonality in the rainfall. The abundance of legumes (table 2) further supports this view. Palaeosol record from northwest Himalaya and quantitative palaeoclimate reconstruction based on pollen assemblage from south India also suggested that during the middle Miocene a monsoonal type of climate was

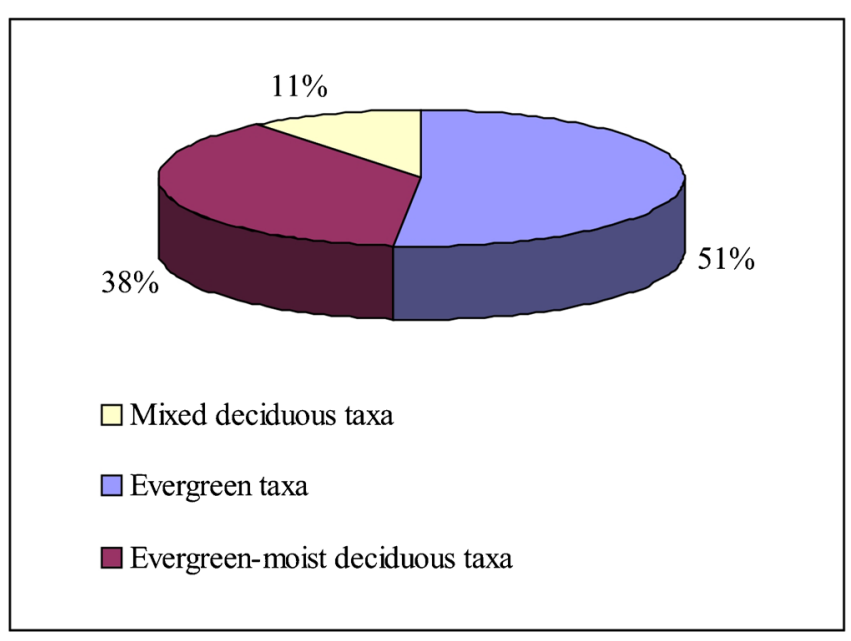

Figure 6. A pie diagram showing distribution of evergreen and deciduous taxa in the fossil assemblage of the studied interval of Lower Siwalik deposits at Kathgodam. 
present in India (Ganjoo and Shaker 2007; Reuter et al. 2012).

\section{Conclusions}

Lagerstroemia (Lythraceae) fossil leaf is described from the middle Miocene (Lower Siwalik) sediments of Kathgodam, Uttarakhand, India. The family Lythraceae had worldwide distribution in the Cenozoic in contrast to modern day tropical to subtropical areas of the world. The present leaf fossil, along with the previous known fossil records of Lagerstroemia, indicates that the genus followed the same pattern of geographic expansion and retraction as the entire family Lythraceae. The plant fossil assemblage from the Lower Siwalik deposits indicates warm and humid climate with seasonality in rainfall in the region during the depositional period.

\section{Acknowledgements}

The authors are thankful to the Directors, Botanical Survey of India, Kolkata and the Forest Research Institute, Dehradun for permission to consult the herbarium. They are also thankful to Prof. Sunil Bajpai, Director, Birbal Sahni Institute of Palaeobotany, Lucknow for providing necessary facilities and permission to carry out this work. A part of this work was carried out under the U.G.C. major project numbered F. No. 39-76/ 2010 (SR), entitled 'Search for Mio-Pliocene Primates and other mammalia in the Siwaliks of Northwest India', awarded to the second author (RG). The authors express their gratitude to Prof. R A Spicer, one anonymous reviewer, and Prof. G V R Prasad for their constructive suggestions to improve the manuscript.

\section{References}

Agarwal A 2002 Contributions to the fossil leaf assemblage from the Miocene Neyveli lignite deposits, Tamil Nadu, India; Palaeontogr. 261B 167-206.

Antal J S and Awasthi N 1993 Fossil flora from the Himalayan foothills of Darjeeling District, West Bengal and its palaeoecological and phytogeographical significance; Palaeobotanist 42 14-60.

Awasthi N 1981 Fossil woods belonging to Sterculiaceae and Lythraceae from the Cuddalore series near Pondicherry; Palaeobotanist 27 182-189.

Bossuyt F and Milinkovitch M C 2001 Amphibians as indicators of early Tertiary 'Out-of-India' dispersal of vertebrates; Science 292 93-95.

Chatterjee S, Goswami A and Scotese C R 2013 The longest voyage: Tectonic, magmatic, and paleoclimatic evolution of the Indian plate during its northward flight from Gondwana to Asia; Gondwana Res. 23 238-267.
Cheng Y-M, Li C-S, Jiang X-M and Wang Y-F 2007 A new species of Lagerstroemioxylon (Lythraceae) from the Pliocene of Yuanmou, Yunnan, China; Acta Phytotax. Sin. 45 315-320.

Chitaley S D and Kate U R 1977 Enigmocarpon sahnii sp. nov. from the Mohgaonkalan beds of India; Rev. Palaeobot. Palynol. 23 389-398.

Choi S-K, Kim K, Jeong E-K, Terada K, Suzuki M and Uematsu H 2010 Fossil woods from the Miocene in the Yamagata Prefecture, Japan; IAWA J. 31 95-117.

Conti E, Litt A, Wilson P G, Graham S A, Briggs B G, Johnson L A S and Sytsma K J 1997 Interfamilial relationships in Myrtales: Molecular phylogeny and patterns of morphological evolution; Syst. Bot. 22 629-647.

Crisp M D, Arroyo M T K, Cook L G, Gandolfo M A, Jordan G J, McGlone M S, Weston P H, Westoby M, Wilf P and Linder H P 2009 Phylogenetic biome conservatism on a global scale; Nature 458 754-756.

Dahlgren R and Thorne R F 1984 The order Myrtales: Circumscription, variation, and relationships; Ann. Missouri Bot. Gard. 71 633-699.

Dilcher D L 1974 Approaches to the identification of angiosperm leaf remains; Bot. Rev. 40 1-157.

Du N 1988 On some silicified woods from the Quaternary of Indonesia; P K Ned Akad Wetensc 91B 339-361.

Dutta S, Tripathi S M, Mallik M, Mathews R P, Greenwood P F, Malagalapalli R R and Summons E 2011 Eocene outof-India dispersal of Asian dipterocarps; Rev. Palaeobot. Palynol. 116 63-68.

Dwivedi H D, Prasad M and Tripathi P P 2006 Fossil leaves belonging to the family Fabaceae and Lythraceae from Siwalik sediments of Koilabas area, western Nepal; Geophytology 36 13-121.

Ellis B, Daly D C, Hickey L J, Johnson K R, Mitchell J D, Wilf P and Wing S L 2009 Manual of Leaf Architecture (Ithaka, New York: Cornell University Press).

Fuchs G and Sinha A K 1974 On the geology of Nainital (Kumaun Himalaya); Himal. Geol. 4 563-580.

Fujiki T, Momohara A and Yasuda Y 2001 Morphology of fossil Lagerstroemia pollen in the interglacial sediments in Japan; Jpn. J. Hist. Bot. 10 91-99.

Ganjoo R K and Shaker S 2007 Middle Miocene pedological record of monsoonal climate from NW Himalaya (Jammu \& Kashmir State), India; J. Asian Earth Sci. 29 $704-714$.

Gaur R 1987 Environment and ecology of early man in northwest India: Geological and palaeontological evidences (Delhi: BR Publishing Corporation).

Graham S A 2013 Fossil records in the Lythraceae; Bot. Rev. 79 48-145.

Graham S A, Hall J, Sytsma K, Shi and Su-Hua 2005 Phylogenetic analysis of the Lythraceae based on four gene regions and morphology; Int. J. Plant Sci. 166 995-1017.

Grimsson F, Zetter R and Hofmann C C 2011 Lythrum and Peplis from the late Cretaceous and Cenozoic of North America and Eurasia: New evidence suggesting early diversification within the Lythraceae; Am. J. Bot. 98 1801-1815.

Guleria J S 1989 Fossil dicotyledonous woods from Bikaner, Rajasthan, India; Geophytology 19 182-188.

Heim A and Gansser A 1939 Central Himalaya; Mem. Soc. Helvetique Sci. Nat. 73 1-245.

Hickey L J 1973 Classification of the architecture of dicotyledonous leaves; Am. J. Bot. 60 17-33.

Hooker J D 1879 The flora of British India. 2 (Kent: L. Reeve and Company).

Johnson L A S and Briggs B G 1984 Myrtales and Myrtaceae: A phylogenetic analysis; Ann. Missouri Bot. Gard. 71 700-756. 
Judy W V, Hari S P, Stogsdill W W, Judy J S, Naguib Y M A and Passwater R 2003 Antidiabetic activity of a standardized extract (GlucosalTM) from Lagerstroemia speciosa leaves in Type II diabetics: A dose-dependence study; J. Ethnopharmacol. 87 115-117.

Kramer K 1974 Die Tertiären Hölzer Südost-Asiens (unter Ausschluss der Dipterocarpaceae); Palaeontogr. 144B 45-181.

Lakhanpal R N and Guleria J S 1981 Leaf- impressions from the Eocene of Kachchh, western India; Palaeobotanist 28-29 353-373.

Lakhanpal R N, Prakash U and Awasthi N 1981 Some more dicotyledonous woods from the Tertiary of Deomali, Arunachal Pradesh, India; Palaeobotanist 27 232252.

Liu Y-S, Zetter R, Ferguson D K and Zou C 2008 Lagerstroemia (Lythraceae) pollen from the Miocene of eastern China; Grana 47 262-271.

Mabberley D J 1997 The plant book, a portable dictionary of the vascular plants (Cambridge: Cambridge University Press).

Mehrotra R C, Dilcher D L and Awasthi N 1998 A Palaeocene Mangifera-like leaf fossil from India; Phytomorphology 48 91-100.

Middlemiss C S 1890 Physical geology of the sub-Himalaya of Garhwal and Kumaon; Geol. Surv. India Memoir 24 29-200.

Miyoshi N, Fujiki T and Morita Y 1999 Palynology of a 250-m core from Lake Biwa: A 430,000-year record of glacial-interglacial vegetation change in Japan; Rev. Palaeobot. Palynol. 104 267-283.

Momohara A, Saiki K and Okuda M 2006 A plant macrofossil assemblage from the Kiyokawa Formation in the Shimosa Group and reconstruction of the palaeoclimate based on it; Quat. Res. (Tokyo) 45 211-216.

Morris J A 2007 A molecular phylogeny of the Lythraceae and inference of the evolution of heterostyly, Unpublished $\mathrm{PhD}$ dissertation, Kent State University, Kent, Ohio.

Peterson A T, Soberon J and Sánchez-Cordero V 1999 Conservatism of ecological niches in evolutionary time; Science 285 1265-1267.

Prakash U 1965a Fossil wood of Lagerstroemia from the Tertiary of Burma; Curr. Sci. 34 484-485.

Prakash U 1965b Some fossil dicotyledonous woods from the Tertiary of eastern India; Palaeobotanist 14 223234.

Prakash U 1972 Fossil woods from the Tertiary of Burma; Palaeobotanist 20 48-70.

Prakash U and Bande M B 1980 Some more fossil woods from the Tertiary of Burma; Palaeobotanist 26 261278.

Prakash U and Tripathi P P 1970 Fossil woods from the Tertiary of Hailakandi, Assam; Palaeobotanist 18 20-31.

Prasad M 1994a Siwalik (middle-Miocene) leaf impressions from the foot hills of the Himalaya, India; Tert. Res. 15 53-90.

Prasad M 1994b Plant megafossils from the Siwalik sediments of Koilabas, central Himalaya, Nepal and their impact on palaeoenvironment; Palaeobotanist 42 126156.

Prasad M 1994c Morphotaxonomical study on angiospermous plant remains from the foot hills of Kathgodam, north India; Phytomorphology 44 115-126.

Prasad M, Ghosh R and Tripathi P P 2004 Floristics and climate during the Siwalik (middle Miocene) near Kathgodam in the Himalayan foot hills of Uttaranchal, India; J. Palaeontol. Soc. India 49 35-93.
Ranga Rao A, Khan K N, Venkatachala B S and Sastri V V 1979 Neogene/Quaternary boundary and the Siwaliks; In: Proceedings of field conference, Neogene-Quaternary boundary (eds) Sastry M V A et al. (Bangalore: GSI), pp. 131-142.

Reuter M, Kern A K, Harzhauser M, Kroh A and Piller W E 2012 Global warming and south Indian monsoon rainfall lessons from the Mid-Miocene; Gondwana Res. 23 11721177.

Rodríguez-de la Rosa R A, Cevallos-Ferriz S R S and SilvaPineda A 1998 Paleobiological implications of Campanian coprolites; Palaeogeogr. Palaeoclimatol. Palaeoecol. 142 $231-254$.

Sahni B 1943 Indian silicified plants 2. Enigmocarpon parijai, a silicified fruit from the Deccan with a review of the fossil history of the Lythraceae; Proc. Indian Acad. Sci. 17B 59-96.

Sahni B and Rode K P 1937 Fossil plants from the Intertrappean beds at Mohgaon Kalan, in the Deccan, with a sketch of the geology of the Chhindwara District; Proc. Natl. Acad. Sci. India 7 165-174.

Salis K V and Saksena R K 1998 Calcarous nanofossils across the $\mathrm{K} / \mathrm{T}$ boundary and the age of Deccan Trap volcanism in southern India; J. Geol. Soc. India 51 183192.

Shukla V B 1944 On Sahnianthus, a new genus of petrified flowers from the intertrappean beds at Mohgaon Kalan in the Deccan and its relation with the fruit Enigmocarpon parijai Sahni from the same locality; Proc. Natl. Acad. Sci. India 14B 1-39.

Shukla V B 1958 Sahnianthus dinectrianum, sp. nov., a new species of the petrified flower Sahnianthus from the Eocene beds of the Deccan; J. Palaeontol. Soc. India 3 114-118.

Shukla P N, Shukla A D and Bhandari N 1997 Geochemical characterization of the Cretaceous-Tertiray sediments at Anjar, India; Palaeobotanist 46 127-132.

Songtham W, Ratanasthien B, Watanasak M, Mildenhall D C, Singharajwarapan S and Kandharosa W 2005 Tertiary basin evolution in northern Thailand: A palynological point of view; Nat. Hist. Bull. Siam Soc. 53 $17-32$.

Srivastava G P and Bande M B 1992 Fossil woods of Terminalia and Lagerstroemia from the late Cenozoic beds of Mahuadanr, Palamu district, Bihar; Palaeobotanist 39 333-337.

Srivastava G and Mehrotra R C 2012 Oldest fossil of Semecarpus L.f. from the Makum Coalfield, Assam, India and comments on its origin; Curr. Sci. $102398-$ 400.

Srivastava G and Mehrotra R C 2013a First fossil record of Alphonsea Hk.f. \& T. (Annonaceae) from the late Oligocene sediments of Assam, India and comments on its phytogeography; PLoS ONE 8 e53177.

Srivastava G and Mehrotra R C 2013b Further contribution to the low latitude leaf assemblage from the late Oligocene sediments of Assam and its phytogeographical significance; J. Earth Syst. Sci. 122 13411357.

Sytsma K J, Litt A, Zihra M L, Pires J C, Nepokroeff M, Conti E, Walker J and Wilson P G 2004 Clades, clocks, and continents: Historical and biogeographical analysis of Myrtaceae, Vochysiaceae, and relatives in the Southern Hemisphere; Int. J. Plant Sci. 166 S85S105.

Tanai T and Uemura K 1991 The Oligocene Noda flora from the Yuya-wan area of the western end of Honshu, 
Japan. Part 1; Bull. Nat. Sci. Mus. (Japan) 17C 5780.

Tandon S K 1976 Siwalik sedimentation in a part of the Kumaon Himalaya, India; Sedim. Geol. 16 131142.

Tiwari A P and Mehdi S H 1964 Geology of Naini Tal Almora Himalaya, U.P. Guide Ex. No. A-4, (New Delhi: Inernt. Geol. Congr. 22, Session), pp. 1-19.
Venkatesan T R, Pande K and Gopalan K 1993 Did Deccan volcanism predate the Cretaceous-Tertiary transition? Earth Planet. Sci. Lett. 119 181-189.

Watanasak M 1990 Mid Tertiary palynostratigraphy of Thailand; J. Southeast Asian Earth Sci. 4 203-218.

Zachos J, Pagani M, Sloan L, Thomas E and Billups K 2001 Trends, rythms, and aberrations in global climate $65 \mathrm{Ma}$ to present; Science 292 686-693.

MS received 24 April 2014; revised 20 August 2014; accepted 30 August 2014 